\title{
Nanoparticle based Wearable Sensor
}

\author{
Ho Kun Woo, Junhyuk Ahn, Soong ju $\mathrm{Oh}^{\dagger}$
}

Department of Material Science and Engineering, Korea university

\section{나노입자 기반의 웨어러블 센서}

\author{
우호균, 안준혁, 오승주 ${ }^{\dagger}$ \\ 고려대학교 신소재공학부
}

(Received February 10, 2019; Accepted March 5, 2019)

\begin{abstract}
s
Recently, wearable sensors have received considerable attention in a variety of research fields and industries as the importance of wearable healthcare systems, soft robotics and bio-integrated devices increased. However, expensive and complex processes are hindering the commercialization of wearable sensors. Nanoparticle presents some of solutions to these problems as its adjustable for processability and tunable properties. In this paper, the recent development of nanoparticle based pressure and strain sensors was reviewed, and a discussion on their strategies to overcome the conventional limitation and operating principles is presented.
\end{abstract}

Keywords: nanoparticle, wearable sensor, pressure sensor, strain sensor

\section{1.서론}

사물인터넷(IoT) 시대 도래와 함께 웨어러블 헬스케어 시스템, 소프트 로보틱스, 그리고 바이오 시스템 통합 분 야에 대한 발전이 두드러졌다. 특히, 웨어러블 센서는 신 체의 자극을 감지하여 전기적 신호로 바꿔 전달하여 사용 자에게 정보를 전달하는데, 이러한 웨어러블 센서의 상용 화를 위해서는 외부 자극에 민감하고 신속하게 반응하는
소재와 구조를 필요로 한다. ${ }^{1}$

웨어러블 센서는 특성상 감지하고자 하는 신체와의 긴 밀한 접촉을 요하기 때문에 울퉁불퉁한 신체와 부드러운 접촉을 하기 위해 유연성을 필요로 한다, 또한, 맥박, 심 장박동, 혈관 수축 등의 작은 움직임도 감지할 수 있는 높 은 민감도(Sensitivity)를 가져야만 한다. 이러한 조건들 을 만족하기 위한 기존의 센서 제작은 복잡하고 비싼 제 작 공정 탓에 단가가 높아 상용화되는데 문제가 되어 왔 
a)

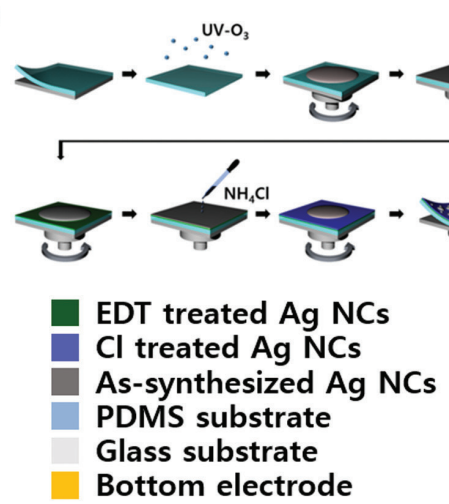

b)

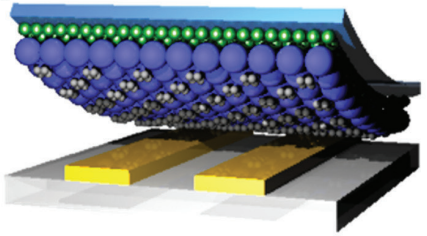

c)

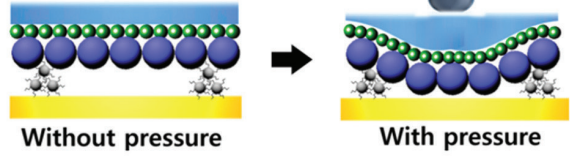

Fig. 1. a) 은 나노입자 미세구조 압력센서 제작 방법 b) 완성된 미세구조 압력센서의 모습 c) 센서의 작동 원리

다. 이러한 문제를 해결하기 위한 방안책으로는 나노입자 가 제시되어왔다. ${ }^{2-4)}$ 나노입자는 크기에 따라 특성이 변 할 뿐이 아니라, 저온, 저진공 상태의 용액공정으로 제작 이 가능하여 기존의 복잡한 공정 과정을 피할 수 있고 유 연 기판과의 접목도 용이하다. 본고에서는 용액공정의 나 노입자를 이용하여 제작한 웨어러블 센서에 대해 다루고 자한다.

\section{2. 웨어러블 센서}

\section{1 압력센서}

압력센서는 외부에서 가해지는 압력을 전기 신호로 변 환함으로써 압력을 감지한다. 최근 들어, 바이오 헬스케 어 분야의 관심이 높아짐에 따라 맥박, 심장박동 등의 신 체의 미세한 신호를 감지할 수 있는 고감도 압력센서의 필요성이 증가하였고, 이를 구현하기 위해 미세구조의 압 력센서가 고안되었다. ${ }^{5-6)}$ 하지만, 앞선 연구에서 제시된 구조들은 고가의 장비들을 통해 고온, 고압 공정을 거처 야 되는 물질적, 비용적 한계가 있었다. 그리하여 본고에 서는 나노입자를 이용하여 상온에서도 손쉽게 제작된 미 세구조 압력센서를 소개하고자 한다.

\subsection{1은 나노 입자 기반 압력센석)}

기존의 미세구조는 기둥, 피라미드, 돔 모양 등을 제작 하여 감도를 높이는 데 성공하였지만, 제작 방법이 어려
워 저가형 고감도 압력센서를 만드는 데는 어려움이 있었 다. 본 연구에서는 타겟 기판의 표면이 고르지 않는다는 특성을 이용하여 은 나노입자 용액 공정의 미세구조 압력 센서를 구현하였다. 본 압력센서는 나노 입자의 리간드에 따라 입자의 전기적 특성이 변하는 점을 이용하여, 나노 입자 분산액을 스핀코팅하고, 리간드 용액을 뿌리는 방식 으로 압력센서의 모든 구조를 완성한다(Fig. 1a). 모든 과 정이 상온, 상압에서 이루어지기 때문에 저가형 헬스케어 센서로 적합한 것으로 평가된다. 해당 압력센서는 저항형 압력센서로 하부전극과 상부전극으로 이루어져 있다 (Fig. 1b). 하부 전극은 서로 $1 \mathrm{~mm}$ 간격으로 떨어져 있도 록 제작하여 전류가 흐르지 않는 상태이고, 상부 전극은 전체적으로 전류가 흐르는 구조로 되어 있다. 이때 압력 이 가해지면 상, 하부가 닿는 면적의 변화로 전제 저항이 변하게 되고 이를 통해 압력 변화를 감지한다(Fig. 1c). 이때 상부 전극 아래에는 특정 리간드에 의해 전류가 흐 르지 않는 은 나노입자가 미세구조로 존재하게 되어 저항 변화의 효과를 극대화하게 된다. 절연성의 은 나노입자는 고르지 않은 표면으로 인해 전체적으로 박막을 형성하지 못하고, 불균일하게 존재하여 상, 하부전극이 압력에 의 해 맞닿을 수 있는 환경을 조성한다.

미세구조를 형성하기 전, 염소로 리간드 치환된 은 나 노 입자 박막만 형성되었을 경우, 상, 하부전극의 접촉면 적이 넓어 압력을 가하기 전 약 $0.1 \mathrm{~mA}$ 의 전류가 $0.1 \mathrm{~V}$ 하 에서 흐른다. 하지만 절연성 은 나노입자로 미세구조를 


\section{특 집 미우호균, 안준혁, 오승주}

a)

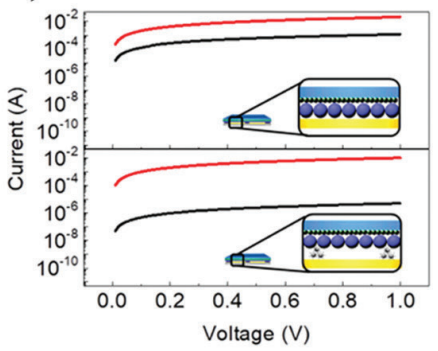

b)

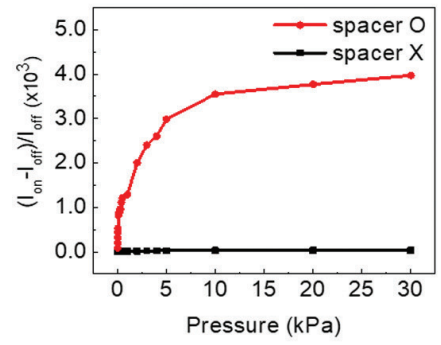

c)

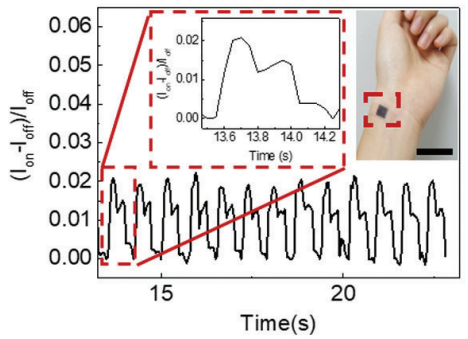

Fig. 2. a) 압력에 따른 전압-전류 그래프 b) 압력에 따른 전류 변화비 그래프 c) 은 나노입자 기반 압력센서로 측정한 맥박
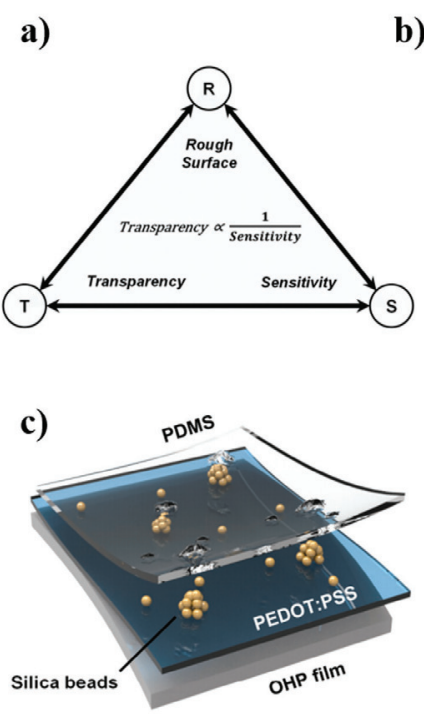

b)
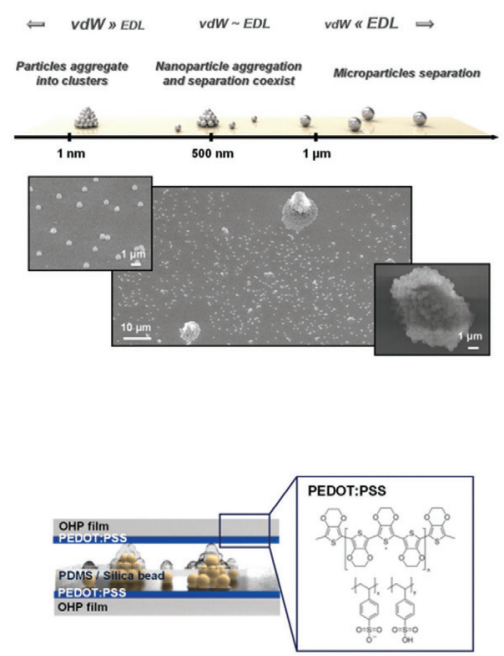

Fig. 3. a) 표면 거칠기, 투명도, 압력센서 감도의 관계 b) 나노입자 크기에 따라 달라지는 입자 응집도 c) 실리카 나노입자 미세구조 압력센서 모식도 비 그래프 c) 은 나노입자 기반 압력센서로 측정한 맥박

형성하게 되면 접촉면적이 급격히 줄어 $0.491 \mu \mathrm{A}$ 가 흐르 게 된다(Fig. 2a). 이로 인해 미세구조의 압력센서의 점 멸비(on/off ratio)는 크게 증가하고 압력센서의 민감도 $\left(\Delta \mathrm{I} /\left(\mathrm{I}_{0} \cdot \mathrm{P}\right)\right.$ 가 $4.16 \pm 2.72 \mathrm{kPa}^{-1}$ 에서 $(4.21 \pm 0.91) \times 10^{2}$ 로 약 100 배 증가한 값을 보일 뿐만 아니라 감지 범위가 $20 \mathrm{kPa}$ 까지 증가하게 된다. (Fig. 2b) 압력센서의 높은 민감도로 인해 손목에 부착하였을 시 맥박을 정확하게 감 지할 수 있다(Fig. 2c).

\subsection{2실리카 나노입자 기반 압력센서8)}

기존의 연구에서는 박막을 거칠게 하는 미세구조를 통 해서 압력센서의 감도를 향상 시켜왔다. 이는 박막의 표
면이 거칠어지는 현상을 야기한다. 박막의 표면이 거칠게 되면 입사하는 빛이 산란하게 되어 사람의 눈에는 뿌옇게 보이게 되어 불투명하다는 단점을 갖고 있다(Fig. 3a). 하지만 본 압력센서 연구에서는 Derjaguin-LandauVerwey-Overbeek 이론을 통해 나노입자의 크기에 따 라 응집력과 분산력이 변하는 것을 발견하고, 분산과 응 집을 적절히 할 수 있는 조건을 찾는 데 성공하였다(Fig. $3 \mathrm{~b})$. 이 조건에서는 Fig. $3 \mathrm{c}$ 와 같이 일부 응집이 된 나노 입자들은 압력센서의 감도를 높일 수 있는 이상적인 미세 구조의 역할을 하였고, 넓게 분산된 나노입자들은 빈 공 간을 만들어 압력센서에 높은 투명도를 부여할 수 있었 다. 해당 압력센서는 투명하면서 전도도가 있는 PEDOT: 
a)

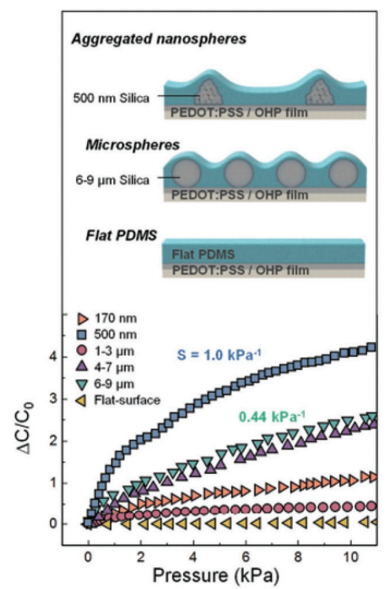

b)
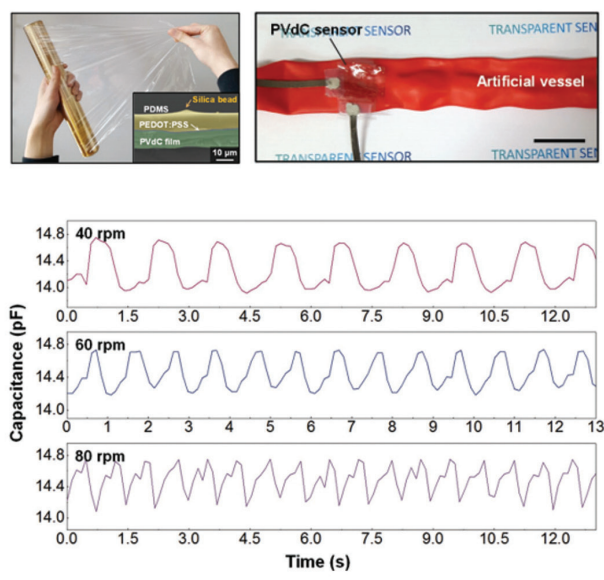

Fig. 4. a) 압력에 따른 정전기 변화비 그래프 b) 실리카 나노입자 기반 압력센서로 측정한 인공혈관의 혈압

$\mathrm{PSS}$ 가 상, 하부에 있고, 사이에 실리카 미세구조와 PDMS (Poly(dimethylsiloxane)) 기판으로 되어 있다. 압력이 가해지면 두 전극 사이가 가까워지게 되고 변화하 는 정전기의 양으로 압력을 감지할 수 있는 구조이다.

실리카 나노입자 미세구조는 응집되면서 고깔 형태를 이루기 때문에, 압력이 가해졌을 때 정전기의 변화를 극 대화할 수 있다. 실제로, 크게 합성된 실리카 마이크로 입 자로 압력센서를 만들었을 때의 감도는 $0.44 \mathrm{kPa}^{-1}$ 로 나 노입자가 모여 미세구조를 만들었을 때의 감도 $1.0 \mathrm{kPa}^{-1}$ 보다 낮았다(Fig. 4a). 실리카 나노입자 미세구조 압력센 서의 높은 감도를 이용해서 압력센서를 인공혈관에 부착 하였을 때 혈압을 성공적으로 측정할 수 있었다(Fig. 4b).

\section{2 스트레인 센서}

스트레인 센서는 측정 대상이 얼마나 변형하는지를 감지 하여 전기적 신호로 변환해주는 센서이다. ${ }^{9-10)}$ 전자기기, 로봇공학, 바이오, 그리고 헬스케어 등에 응용될 수 있는 만큼, 스트레인 센서의 관심이 증가하는 추세이다. 하지 만 기존의 스트레인 센서는 감도가 낮거나, 공정이 복잡 하다는 단점이 있다. 이러한 문제점을 해결하기 위해 나 노입자 기반의 스트레인 센서가 고안되었다. 앞서 언급한
나노입자의 장점인 고감도 (Sensitivity), 저가형 공정 과 정을 이용하면 이러한 문제를 상당량 극복할 수 있다. 그 리하여 본고에서는 나노입자의 다양한 특성을 이용하여 단점을 개선한 스트레인 센서들을 소개하고자 한다.

\subsection{1 리간드 길이 조절법 기반 스트레인 센서11)}

전도성 물질인 금속 나노입자가 부착된 유연기판에 변 형이 발생하게 된다면 입자간 거리가 달라지게 되어 전도 도에 변화가 발생한다. 이러한 변화를 측정하여 얼마만큼 의 변형이 발생하였는지를 계산하는 것이 저항 기반 스트 레인 센서이다. 나노입자를 이용한 저항 기반의 스트레인

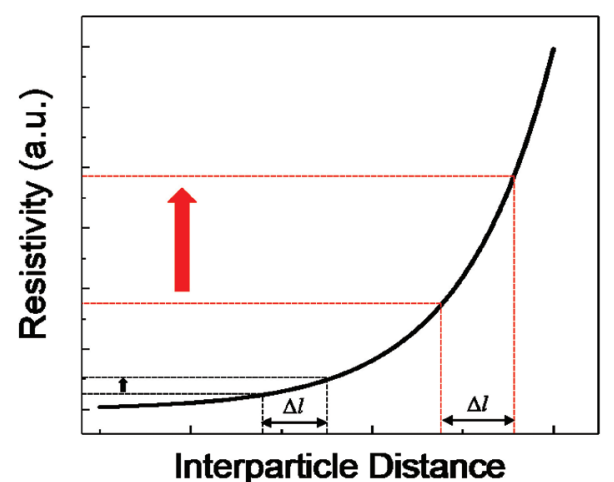

Fig. 5. 초기저항에 따라 입자간 거리의 변화가 얼마만큼의 저항 변 화를 보여주는지에 대한 그래프. 


\section{특 집 $\quad$ 우호균, 안준혁, 오승주}

센서는 상온에서의 제작이 가능하기 때문에 고온에 취약 한 유연 기판과 호환이 된다는 장점이 있다. 또한, 저진 공에서의 공정 과정으로 인해 제작비용을 낮출 수 있다는 장점이 있다.

금속 나노입자가 긴 길이의 리간드 올레이트기에 둘러 싸이게 되면 입자의 간격이 멀어지게 되어 전도도가 현저 하게 떨어지게 된다. 반대로 길이가 짧은 리간드로 금속 나노입자를 패시베이션(Passivation)하게 된다면 전자 가 금속성 전도(Metallic transport)를 점차 띄게 되어 전도도가 향상하게 된다. 이러한 점을 이용하여 Fig. 5 와 같이 초기저항을 증가시킨다면 제작한 센서의 민감도 (Sensitivity)를 올리게 되어 스트레인 센서의 성능 지표 인 게이지팩터(Gauge Factor)를 향상시킬 수 있다. 게이 지 팩터 $(\mathrm{G})$ 에 대한 수식은 다음과 같다.

$$
G=\frac{\Delta R / R_{o}}{\varepsilon} \quad \text { 수식 (1) }
$$

$\triangle R$ 은 변화한 저항값 - 초기 저항값, $R_{o}$ 는 초기 저항 값, 그리고 $\varepsilon$ 은 유연기판 두께에 따른 스트레인(\%)이다. 이 지표를 이용하면 스트레인 센서의 성능을 비교할 수 있다.

Fig. 6에서는 각 리간드에 따라 변화하는 전기적, 전
기-기계적 특성을 분석하였다. Fig. $6 a$ 에서는 기판에 변 형이 가해짐에 따라 입자간 거리가 달라지게 되어 변화하 는 전도도를 I-V curve를 통해 분석하였다. 기판이 구부 러지지 않은 상태(검은선)보다 기판에 변형이 발생한 상 태(빨간선)가 더 낮은 전도도를 나타내는 것을 확인할 수 있다. Fig. $6 \mathrm{~b}$ 는 기판에 걸리는 스트레인에 따라 저항 변 화가 얼마나 일어나는지를 비교하였다. 가해지는 스트레 인이 높아질수록 선형으로 비례하게 증가하는 것을 볼 수 있다. Fig. $6 c$ 에서는 제작된 센서가 안정적으로 여러 번 작동한다는 것을 보여준다. Fig. $6 \mathrm{c}-\mathrm{d}$ 는 은 나노입자 기 반에 각기 길이가 다른 리간드를 이용하면 달라지는 저항 변화율을 나타내고 있다. 가장 길이가 긴 리간드 (보라색) 와 가장 짧은 리간드(빨간색)을 비교하여 약 1.4 에서 274 까지의 게이지 팩터를 비교, 분석하였다. 가장 긴 리간드 가 가장 높은 저항 변화율을 보였고, 반대로 리간드의 길 이가 짧은 리간드는 적은 저항 변화율을 보였다. 이러한 분석 결과는 리간드의 길이가 길수록 스트레인에 따른 저 항변화가 커지고, 길이가 짧은 리간드는 저항변화에 둔감 한 것을 보여준다.

위와 같은 분석을 통해 Fig. 7에서는 거리가 긴 리간드 (Oleate, MPA, EDT 등)에 둘러싸여 있는 은 나노입자를 감지층으로 두고, 길이가 짧은 리간드 $(\mathrm{Cl}, \mathrm{Br}, \mathrm{I}, \mathrm{OH}$ 등 $)$
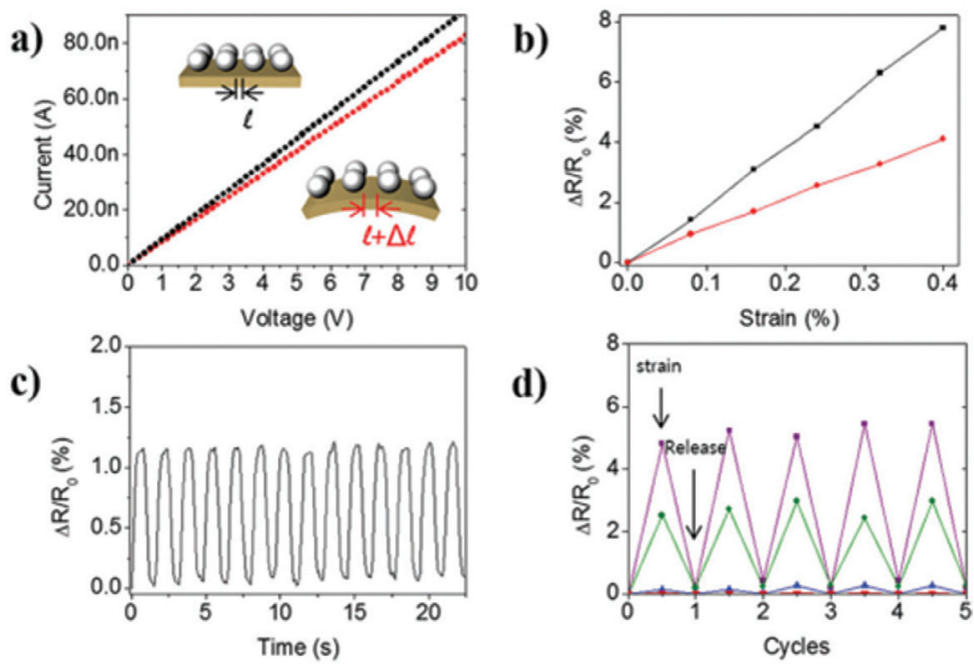

Fig. 6. a) I-V curve 그래프를 통한 기판에 스트레인이 걸렸을 때 생기는 전도도의 변화, b) 스트레인이 얼마나 걸리는지에 따른 저항값의 변 화, c) 여러 번 진행되어도 성능의 변화가 없음을 보여주는 그래프, d) 리간드 길이에 따른 저항변화 비교 그래프. 


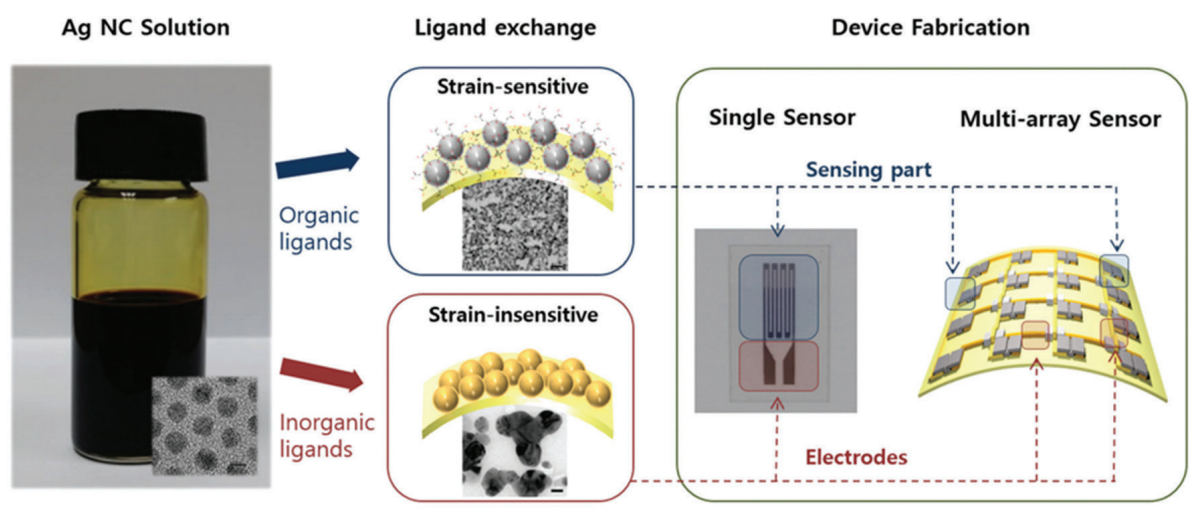

Fig. 7. 입자간 거리에 따른 전도도를 이용한 전극, 센서 제작 모식도
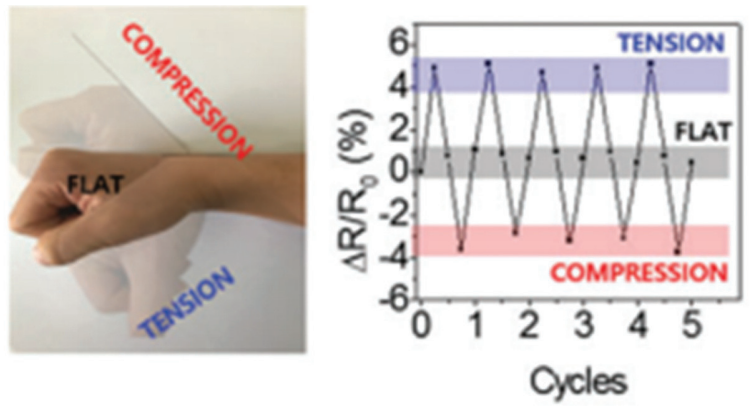

Fig. 8. 소자를 이용한 센서의 사용과 성능 그래프

에 둘러싸인 은 나노입자는 초기저항이 작아 저항변화에 민감하지 않으므로 전극으로 썼음을 보여준다. 같은 나노 입자를 이용하여도 둘러싸고 있는 리간드의 길이에 따라 저항의 변화가 얼마만큼 발생하는지를 비교하여 상황에 맞는 디바이스를 제작할 수 있음을 보여준다.

긴 리간드를 통해 입자간 거리를 늘려서 높은 감지도를 갖는 센서를 제작하였다. 제작된 소자는 Fig. 8와 같이 손목이 위, 아래로 움직일 때의 저항변화를 측정하여 손 목의 움직임을 감지하였다.

\subsection{2 부분 리간드 치환법을 통한 웨어러블 센서 ${ }^{12)}$}

리간드 길이에 따른 전도도 변화나 특성 분석이 많이 이루어졌으나 리간드 치환 과정에 관한 연구는 많이 진행 되지 않았다. 단순히 리간드의 길이만을 이용하여 센서의 민감도를 제어하는 것은 물질에 대한 연구와 성능 향상의 한계가 존재한다. 하지만 본 연구에서는 한 가지의 리간

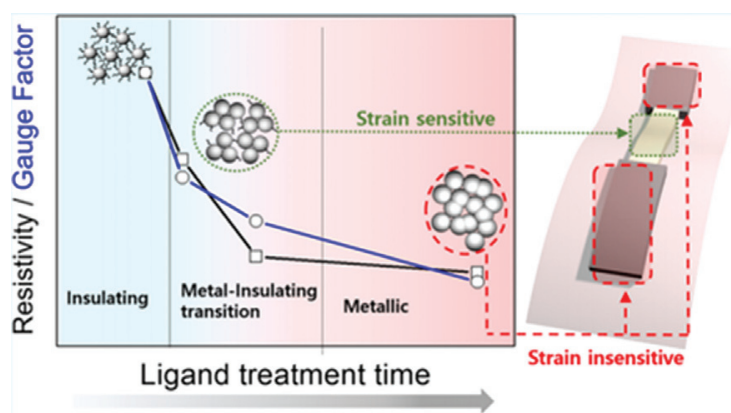

Fig. 9. 리간드 치환 시간에 따른 입자의 형태 (morphology) 모식도

드와 나노입자만을 이용하여 전도도가 높은 전극을 만들 었을 뿐만 아니라 민감도가 높은 스트레인 센서를 제작하 였다. Fig. 9 가 보여주는 것처럼, 처음 둘러싸고 있는 올 레이트 (Oleate) 리간드를 길이가 짧은 브롬 리간드 $(\mathrm{Br}-)$ 로 바꿔주면서 점차 입자간 간격이 줄어들어 결국 뭉쳐지는 것을 보여준다. 뭉쳐진 상태에서는 금속의 성질 을 나타내지만 올레이트 리간드가 남아있을 때는 금속의 성질과 절연성 모두 부분적으로 나타나게 된다. 이를 이 용하여 한 가지 물질만을 이용하여 전극과 감지 센서를 만들었을 뿐만 아니라 리간드 치환 과정의 이해를 통해 게이지 팩터를 약 334 까지 향상하였다.

치환 시간에 따라 올레이트기가 사라지는 것을 $\mathrm{FT}-\mathrm{IR}$ 스펙트럼 Fig. 10a을 통하여 분석하였다. 치환하기 전 (빨간선)에서 치환이 완료되는 시점 (보라색 선)으로 갈 수록 $2800 \sim 3000 \mathrm{~cm}^{-1}$ 파수의 픽이 사라지는 것을 볼 수 있다. 이는 점점 올레이트기가 떨어지는 것을 의미한 

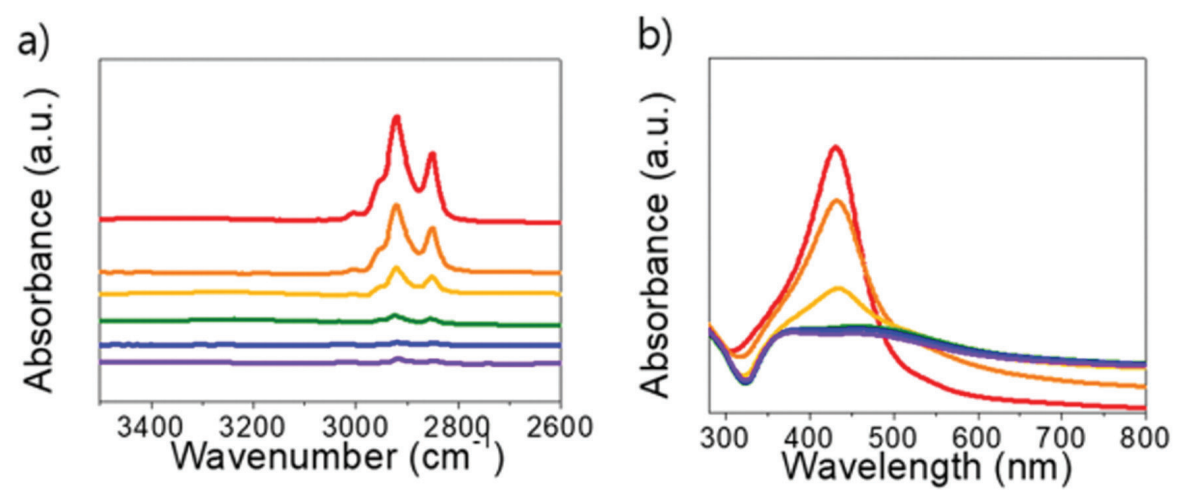

Fig. 10. a) 치환 시간에 따른 $\mathrm{FT}-\mathrm{R}$ 스펙트럼, b) 치환 시간에 따른 UV-Vis 스펙트럼 분석

다. 또한, LSPR (Locallized Surface Plasmon Resonance) 픽을 통해 은 나노입자의 사이즈가 어떻게 변화하는지를 분석할 수 있다. 이 스펙트럼은 (Fig. 10b) 에 나타나있다. 입자 사이즈가 커질수록 LSPR이 사라지 게 되므로 올레이트가 다 붙어있는 상태(빨간선)에서 올 레이트 리간드가 다 떨어진 상태(보라색 선)로 갈수록 $\mathrm{LSPR}$ 픽이 사라지는 것을 관찰할 수 있다. 이러한 데이터 분석을 통해 시간이 지날수록 올레이트기가 모두 치환되 면서 은 나노입자끼리 뭉쳐지는 것을 유추해낼 수 있다.

리간드 치환의 제어를 통해 부분적으로 치환하면 Fig. 11. 에서 나타난 것처럼 전자의 이동을 제어할 수 있게 된 다. 올레이트가 다 떨어져서 금속의 성질을 띄는 부분으 로 전자가 이동하게 되고 긴 올레이트에 의해 거리가 먼 곳은 전자의 이동이 방해되어 전자가 잘 흐르지 못하게 된다. 유연 기판에 스트레인이 걸리게 되면 입자간 거리 가 더 멀어지게 되면서 전자의 이동이 더욱더 제한된다. 즉, 부분적으로 치환하면 전자의 이동을 제어하게 됨으로
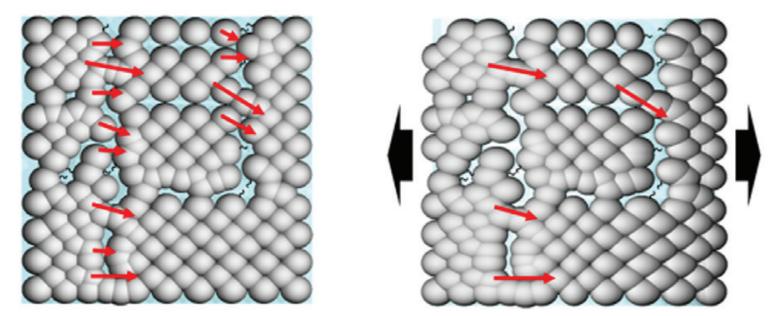

Fig. 11. 스트레인이 걸릴 때의 전자 이동 모식도
써 더 높은 게이지 팩터를 얻을 수 있게 된다.

리간드 부분치환법을 이용하여 스트레인 센서를 제작 하는 공정 과정을 Fig. 12a에 나타내었다. (Fig. 12b-c) 는 제작된 스트레인 센서를 각각 손가락의 굽힘, 성대의

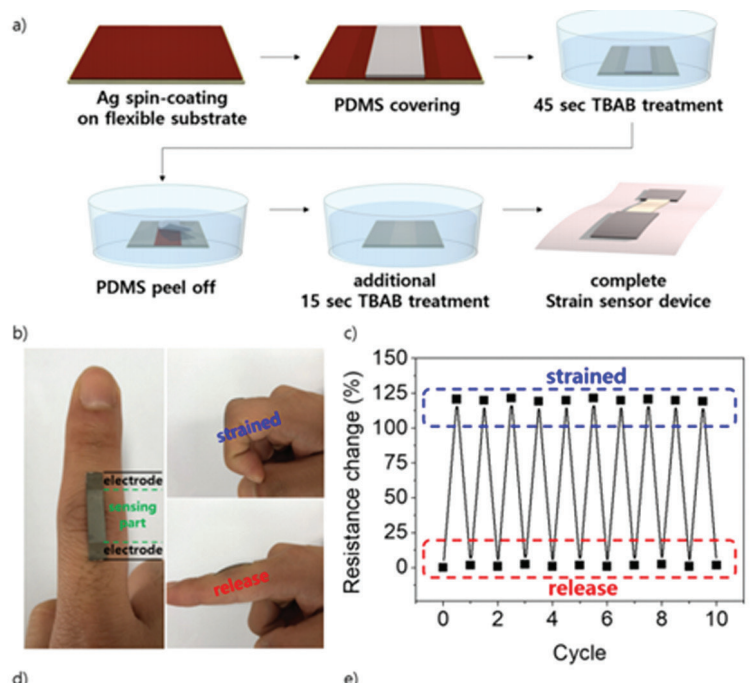

d)
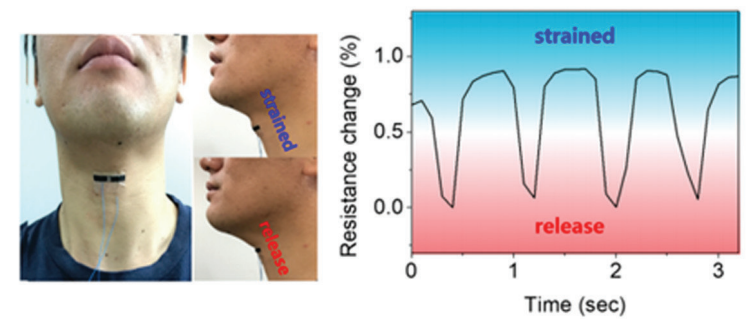

Fig. 12. 스트레인 센서의 제작 공정과 어플리케이션 
a)

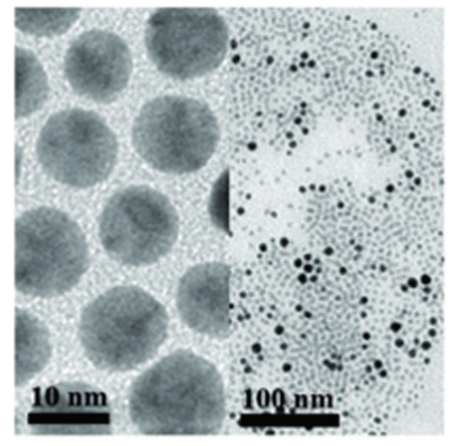

\section{b)}

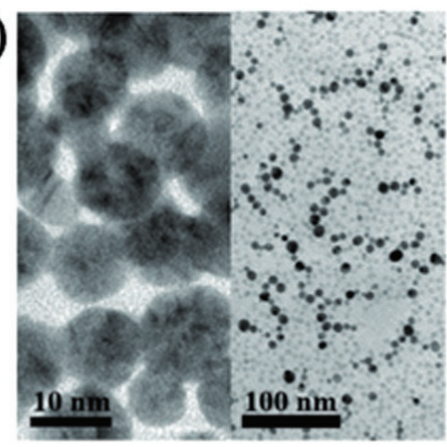

c)

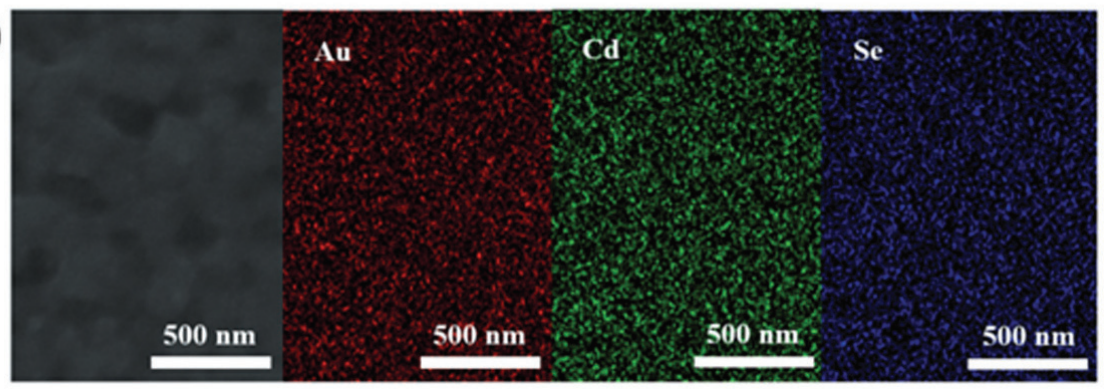

Fig. 13. a) 올레이트기에 둘러싸인 금 나노입자의 SEM 이미지, b) 리간드 EDT에 둘러싸인 금 나노입자 (좌)와 $77 \%$ 의 CdSe 나노입자가 섞인 $\mathrm{SEM}$ 이미지 (우), 그리고 c) 금 나노입자와 카드뮴셀레나이드 입자의 맵핑 (mapping) 이미지

움직임을 감지하기 위해 신체에 부착한 사진이다. 각각의 센서는 Fig. $12 \mathrm{~d}-\mathrm{e}$ 에서 나타난 것과 같이 손가락과 성 대의 움직임을 성공적으로 감지하였다.

\subsection{3금속-절연체 나노입자 이종 구조 기반 스트레인 감지 센서 ${ }^{13)}$}

리간드 크기의 조절과 한 종류의 나노입자의 리간드 제 어를 통한 게이지 팩터 향상 등 한 가지 나노입자를 이용 한 연구는 많이 되어 왔다. 하지만 나노입자 기반의 더 높 은 게이지 팩터를 갖는 소자는 아직 발표된 바가 없다. 더
높은 민감도를 갖는 스트레인 감지 센서를 제작하기 위해 이 논문에서는 금속성을 갖는 나노입자 $(\mathrm{Au})$ 와 절연성인 물질 $(\mathrm{CdSe})$ 을 배치하여 전자의 이동을 제어하였다. 이러 한 방법을 통해 더 높은 게이지 팩터를 갖게 되었다.

Fig. $14 \mathrm{a}$ 에서는 절연체인 $\mathrm{CdSe}$ 나노입자의 비중에 따 른 저항값을 비교하였다. CdSe 나노입자가 들어갈수록 초기 저항값이 높아지는 것을 이용하여 게이지 팩터를 향 상하였다. Fig. 14b에서는 전도성 물질인 금 나노입자만 사용했을 때와 $\mathrm{CdSe}$ 나노입자를 적절히 섞어주었을 때 의 저항변화를 나타낸다. $77 \%$ 의 CdSe가 포함되어 있을
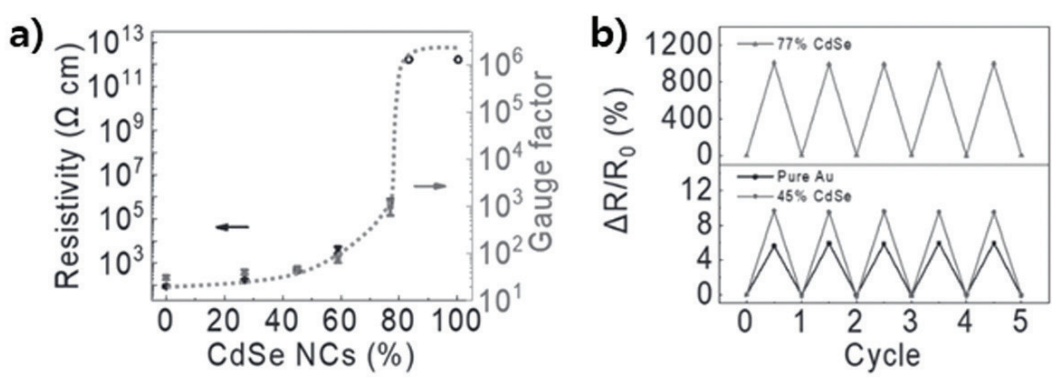

Fig. 14. a) CdSe 나노입자의 비율에 따른 저항값과 게이지 팩터, b) CdSe의 비율에 따른 저항변화율 
a)

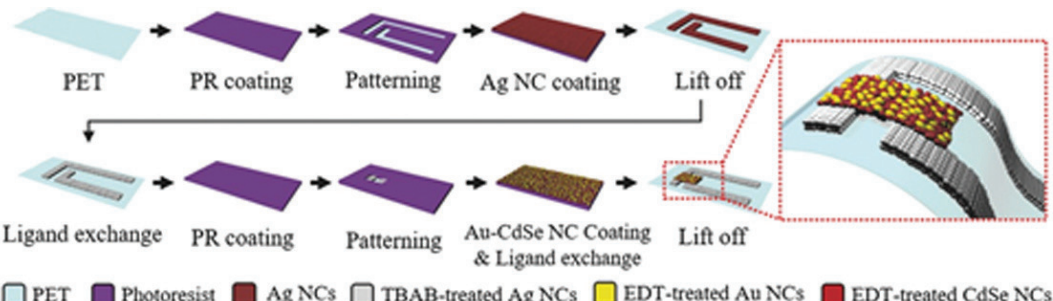

b)

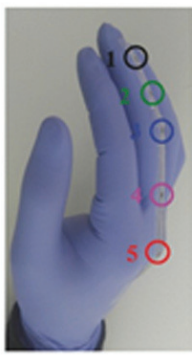

d)

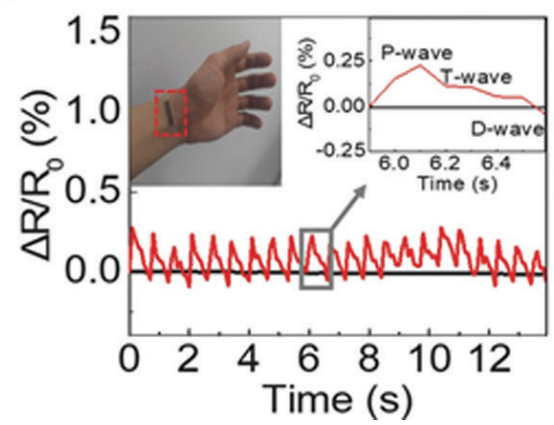

c)

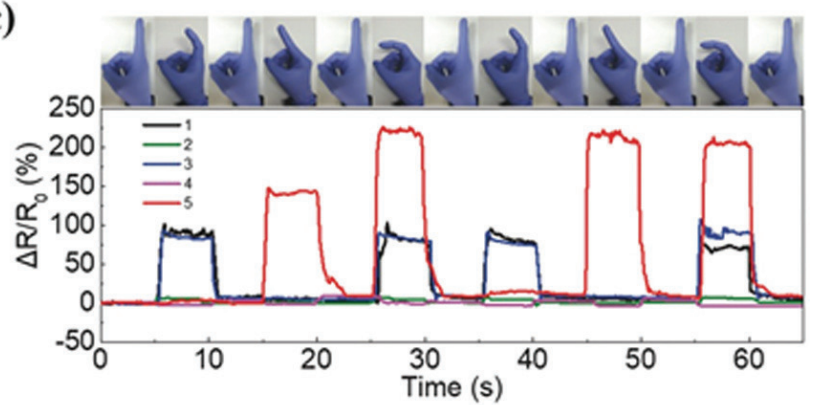

e)

Fig. 15. 이종나노입자를 이용한 센서의 어플리케이션

때가 순수한 금 나노입자로만 이루어진 소자보다 약 500 배 높은 1000 정도의 게이지팩터를 보였다.

고감도의 소재를 이용하여 Fig. $15 \mathrm{a}$ 와 같이 소자를 제 작하였다. 제작된 소자는 Fig. $15 \mathrm{~b}-\mathrm{e}$ 에서 보는 것과 같 이 손가락의 움직임부터 맥박, 목소리로 인한 성대의 움 직임 등을 감지할 수 있었다.

\subsection{4유연소자 위 나노입자의 패터닝(Patterning)을 통한 스트레인 감지센서(1)}

나노입자 혹은 나노입자의 표면 성질에 따른 전기적, 전기-기계적 특성 연구는 많이 진행되어왔다. 이러한 나 노입자는 각 쓰임새에 맞게 패터닝을 하여 회로나 캐패시 터, 솔라셀, 디스플레이 그리고 센서와 같은 분야에 이용

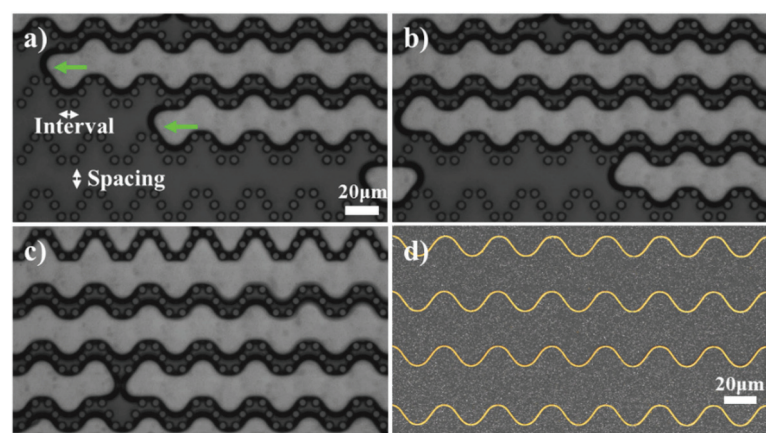

Fig. 16. a-c) 액상의 은 나노입자가 패터닝 된 실리콘 기둥을 따 라 어셈블 (Assembly) 되는 과정을 보여주는 SEM 이미지, d) 은 나노입자가 어셈블을 통해 패터닝 된 모습을 보여주 는 SEM 이미지.

되고 있다. 하지만 이러한 패터닝 기술은 실리콘이나 유 리와 같은 딱딱한 기판에서의 연구가 주를 이루고 있다. 
건강에 대한 관심이 증가함에 따라 사람의 심장박동이나 목소리, 혈류량 등 건강과 관련된 생체신호를 감지하기 위한 연구가 진행되고 있지만 아직 결과는 미미한 상황이 다. 미세한 신호를 감지하기 위해서는 이러한 딱딱한 기 판보다 신체에 부착할 수 있는 유연 소자를 기반으로 한 센서를 필요로 한다. 유연 기판에서의 패터닝에는 기술적 한계와 공정 과정의 복잡함으로 인해 고비용을 초래하여 쉽게 성과를 내지 못하고 있다. 하지만 본 연구에서는 나 노입자의 어샘블리(Assembly)를 이용하여 유연소자 위 에 패터닝을 하고 적은 공정 과정을 통해 디바이스를 제 작하였다.

Fig. 16에서는 은 나노입자의 어샘블리를 통한 패터닝 을 보여준다. 유연기판인 $\mathrm{PDMS}$ 에 실리콘 기둥이 패터닝 되어 있는 템플릿을 꽂은 후 은 나노입자를 코팅하였다. 코팅된 은 나노입자는 어샘블(Assemble) 되어 원하는 곡 률을 갖는 웨이브(Wave)로 패터닝이 되었다.

패터닝 된 은 나노입자에 따른 특성을 Fig. 17에 나타 내었다. 곡선의 곡률이 낮을수록 외부에서 가해지는 변형 에 둔감해지는 것을 볼 수 있다. a)

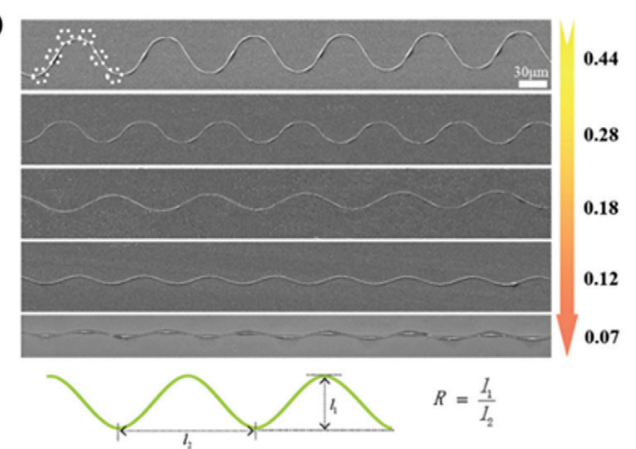

b)

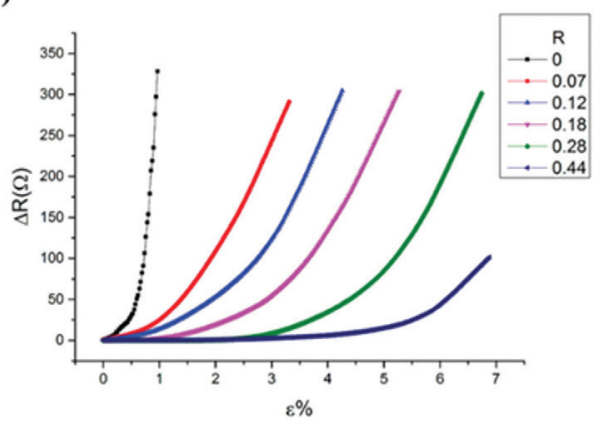

Fig. 17. a) 곡률 (R)에 따른 SEM 이미지, b) 곡률에 따라 외부에 서 가해지는 변성에 저항이 얼마나 변화하는지를 보여주 는 그래프.

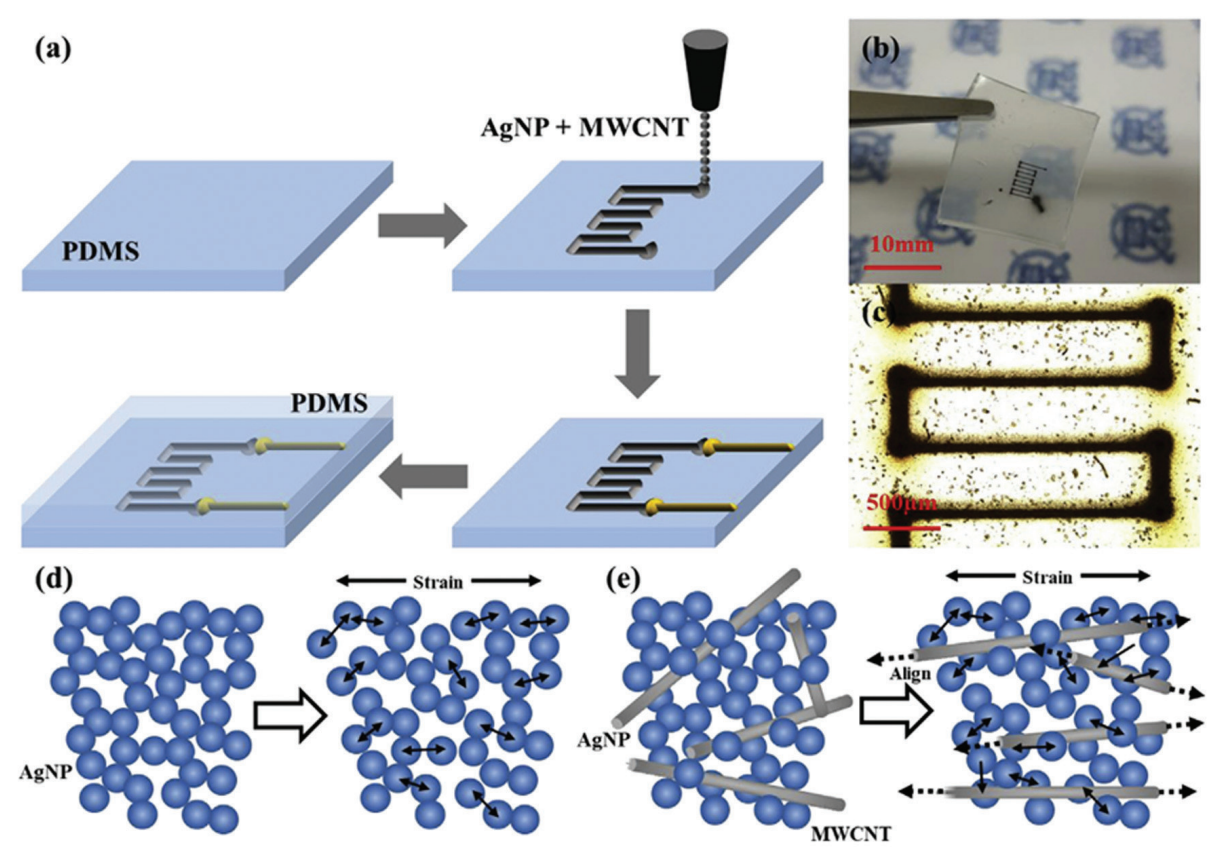

Fig. 18. a) 나노혼합물 센서의 제작과정을 보여주는 모식도, b) 제작된 샘플의 사진, c) 제작된 샘플의 광학이미지, d) 은 나노입자만 있을 경 우의 모식도, 그리고 e) 은 나노와이어와 같이 있을 때의 모식도. 


\section{특 집 ㅁㅁ우호균, 안준혁, 오승주}

이러한 점을 이용한다면 같은 물질을 이용하면서도 패 터닝에 따라 전극으로 쓰기도, 스트레인을 감지하는 센서 로 쓸 수도 있을 것이다.

\subsection{5나노입자와 나노와이어의 혼합을 통한 스트레쳐블 (Stretchable) 스트레인 센서15-16)}

금속 나노입자를 이용한 스트레인 센서는 높은 감지도 를 갖는 것으로 연구가 되었다. 하지만 높은 감지도를 갖 는 것은 동시에 낮은 스트레쳐블(Stretchable) 디바이스 가 된다는 것을 야기한다. 이러한 한계를 극복하기 위해 본 연구에서는 나노입자와 카본 나노튜브(CNTs)를 혼합 하였다. 카본 나노튜브의 경우, 기계적 특성과 전기적 특 성이 모두 좋기 때문에 전도도를 유지하면서도 잘 늘어나 는 것으로 알려져 있다. 이러한 장점들을 이용하여 외부 변화에 따른 변성을 감지하면서도 잘 늘어나는 소자 제작 하였다.

Fig. 18에서는 은 나노입자를 패터닝하는 과정과 혼합 물(Composites)에 따른 변화를 모식화하였다. Fig. 18a 에서는 PDMS 위에 은 나노입자와 MWCNTs (Multiwalled carbon nanotubes) 혼합물을 패터닝하는 과정 을 보여준다. 실리콘과 유리와 같은 딱딱한 기판 위에서 는 많은 연구를 통해 최적화된 패터닝 기술이 있지만 $\mathrm{PDMS}$ 와 같은 유연기판 위에서는 원하는 모양의 패터닝 을 하기가 쉽지 않다. 그리하여 프린팅 기술을 이용하여 기판 위에 혼합물을 뿌려서 패터닝을 하였다. 제작된 소 자는 Fig. 18b에서 보는 것과 같이 아주 작은 면적으로 제 작될 수 있다. 소자의 크기는 약 $15 \mathrm{~mm}$ 이내이며 패턴된 너비는 Fig. $18 \mathrm{c}$ 에서 나타난 것처럼 약 $0.5 \mathrm{~mm}$ 이다. 기 존에 많이 연구되어 오던 나노입자만으로 제작된 스트레 인 센서는 Fig. 18d의 모식도에서 나타내고 있는 것과 같 이, 소자의 길이에 변화가 일어나게 되면 입자간 거리가 멀어지게 된다. 나노입자의 경우 Tunneling/hopping mechanism으로 인해 전자가 움직이게 되는데, 외부 힘 에 의한 길어진 입자간 거리로 인해 전도도의 변화가 크 게 나타나는 것이다. 이와 반대로 MWCNTs를 섞은 소자 의 경우, 입자간 거리가 멀어지더라도 전도성이 좋은 MWCNTs에 의해 전도도가 크게 달라지지 않는다. a)

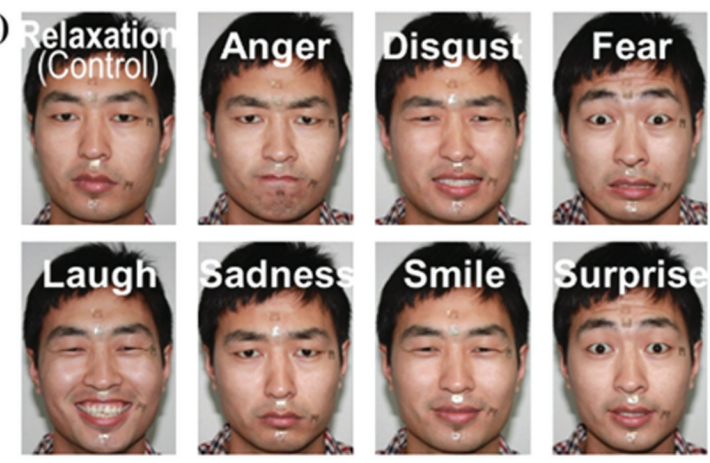

b)
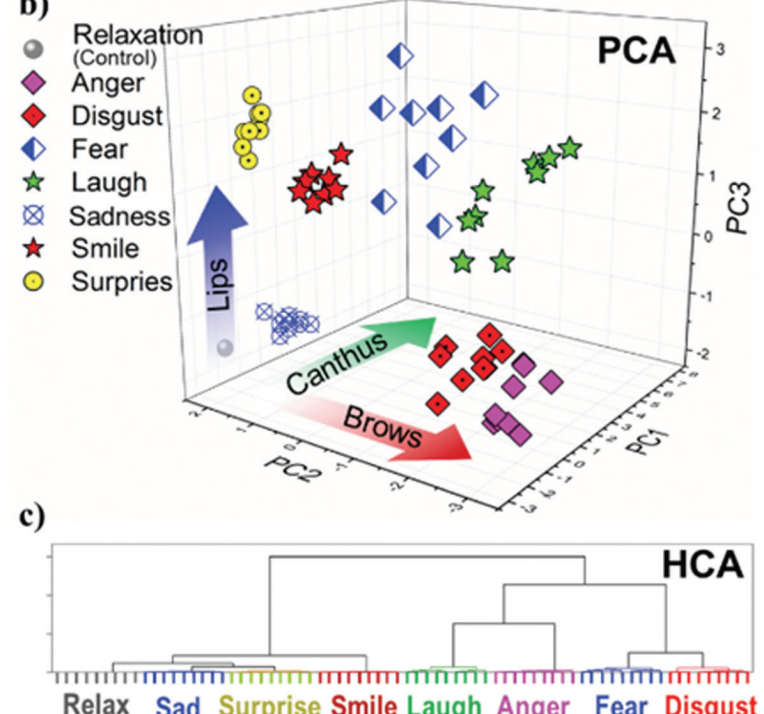

Relax Sad Surprise Smile Laugh Anger Fear Disgust

Fig. 19. 각 표정에 따른 분석 그래프

신축성이 좋은 MWCNTs와 감지도를 높일 수 있는 나 노입자를 적절히 섞는다면 스트레쳐블한 스트레인 감지 센서를 제작할 수 있을 것이다.

Fig. 19에서는 각 표정에 따른 변화를 관찰하여 입술, 눈썹, 그리고 눈의 양 끝 등 표정에 따라 안면의 근육이 움직이는 곳에 제작한 스트레인 센서를 부착하였다. 부착 된 센서는 각각의 움직임을 관찰하고 분석하여 편안함, 행복, 공포, 혐오감 등의 감정을 분류하였다.

\section{3. 결론}

사람을 대신해 감지해주는 센서는 사물인터넷 시대에 맞춰 앞으로 더욱더 시장을 확대해 갈 것이다. 특히, 전 
자기기들이 웨어러블 및 소형화가 됨에 따라 고감도 웨어 러블 센서의 중요성이 부각될 것이다. 본고에서는 기존의 웨어러블 센서에서 가장 큰 문제로 제시되었던 복잡하고 비싼 공정을 나노입자로 해소할 수 있는 방법을 제시하였 다. 용액의 나노입자는 상온, 저진공에서 제작이 가능하 므로, 기존 센서 공정을 간소화해 비용절감을 할 수 있을 뿐만 아니라 나노입자의 특성을 이용하여 고감도의 조건 까지 만족할 수 있어 더 많은 발전 가능성을 지니고 있다. 나노입자의 용액공정을 이용한 센서는 추후 더 나아가 전 자피부, 다기능 센서 등 더욱 다양한 산업분야에 큰 기여 를 할 것으로 기대된다.

\section{참고문헌}

1. M. L. Hammock, A. Chortos, B. C. Tee, J. B. H. Tok, Z. Bao, "25th Anniversary Article: The Evolution of Electronic Skin (E-Skin): A Brief History, Design Considerations, and Recent Progress." Adv. Mater. 25, $5997-6038$ (2013).

2. S. H. Ko, H. Pan, C. P. Grigoropoulos, C. K. Luscombe, J. M. J. Frechet, and D. Poulikakos, "Allinkjet-printed flexible electronics fabrication on a polymer substrate by low-temperature highresolution selective laser sintering of metal nanoparticles" Nanotechnology. 18, 345202 (2007).

3. J. Yin, P. Hu, J. Luo, L. Wang, M. F. Cohen, and C. J. Zhong, "Molecularly mediated thin film assembly of nanoparticles on flexible devices: electrical conductivity versus device strains in different gas/ vapor environment." ACS Nano. 5, 6516 (2011).

4. M. Kang, K. J. Baeg, D. Khim, Y. Y. Noh, and D. Y. Kim, "Printed, Flexible, Organic Nano-FloatingGate Memory: Effects of Metal Nanoparticles and Blocking Dielectrics on Memory Characteristics" $A d V$. Funct. Mater. 23, 3503 (2013).

5. J. Ge, L. Sun, F. R. Zhang, Y. Zhang, L. A. Shi, H. Y. Zhao, H. W. Zhu, H. L. Jiang, S. H. Yu,"A Stretchable Electronic Fabric Artificial Skin with Pressure-, Lateral Strain-, and Flexion-Sensitive Properties." Adv. Mater. 2016, 28, 722 - 728.

6. Y. Zang, F. Zhang, C. A. Di, D. Zhu, "Advances of Flexible Pressure Sensors toward Artificial Intelligence and Health Care Applications." Mater. Horizons 2015, 2, $140-156$.

7. H. Kim, S. -W. Lee, H. Joh, M. Seong, W.S. Lee, M.
S. Kang, J. B. Pyo, S. J. Oh, "Chemically Designed Metallic/Insulating Hybrid Nanostructures with Silver Nanocrystals for Highly Sensitive Wearable Pressure Sensors.", ACS Appl. Mater. Interfaces, 10, 1389-98 (2018).

8. H. Kim, G. Kim, T. Kim, S. Lee, D. Kang, M. S. Hwang, Y. Chae, S. Kang, H. Lee, H. G. Park, "Transparent, Flexible, Conformal Capacitive Pressure Sensors with Nanoparticles.”Small, 14, 170342 (2018).

9. Y. Wang, L. Wang, T. Yang, X. Li, X. Zang, M. Zhu, K. Wang, D. Wu, H. Zhu, "Wearable and Highly Sensitive Graphene Strain Sensors for Human Motion Monitoring." Adv. Funct. Mater. 24, 4666-4670. (2014).

10. C. Pang, G. Y. Lee, T. Kim, S. M. Kim, H. N. Kim, S. H. Ahn, K. Y. Suh, "A Flexible and Highly Sensitive Strain-Gauge Sensor Using Reversible Interlocking of Nanofibres."Nat. Mater. 11, 795 -801. (2012).

11. S.-W.Lee, H. Joh, M. Seong, W. S. Lee, J.-H. Choi, and S. J. Oh, "Engineering Surface Ligands of Nanocrystals to Design High performance Strain Sensor Arrays through Solution Process.", J. Mater. Chem. C, 5, 2442 (2017).

12. W.S. Lee, S. -W. Lee, H. Joh, M. Seong, H. Kim, M. S. Kang, K. -HCho, Y.-M. Sung, S. J. Oh, "Designing metallic and insulating nanocrystal heterostructures to fabricate highly sensitive and solution processed strain gauges for wearable sensors.”, Small, 13, 1702534 (2017).

13. S. -W. Lee, H. Joh, M. Seong, W.S. Lee, J.-H. Choi*, S. J. Oh*, "Transition States of Nanocrystal Thin Films During Ligand Exchange Processes for Potential Application in Wearable Sensors," ACS Appl. Mater.\& Interfaces, 10, 25502 (2018).

14. M. Su, F. Li, S. Chen, Z. Huang, M. Qin, W. Li, X. Zhang, Y. Song, "Nanoparticle Based Curve Arrays for Multirecognition Flexible Electronics.", $A d v$. Mater. 28, 1369 (2016)

15. S. Zhang, H. Zhang, G. Yao, F. Liao, M. Gao, Zh. Huang, K. Li, Y. Lin, "Highly stretchable, sensitive, and flexible strain sensors based on silver nanoparticles/carbon nanotubes composites.", Journal of Alloys and Compounds, 652, 48 (2015)

16. S. Min, G. Lee, S. Ahn, "Direct printing of highly sensitive, stretchable, and durable strain sensor based on silver nanoparticles/multi-walled carbon nanotubes composites.", Composites Part B, 161, 395 (2019) 


\section{특 집 ㅁㅁ 우호균, 안준혁, 오승주}

\section{ㅇㅇ우호 균}

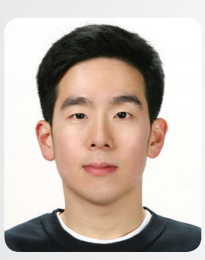

○ 2013-2018 고려대학교 신소재공학 학사

( ) 2018-현재 고려대학교 신소재공학 석사과정

\section{ㅇ안 준 혁}

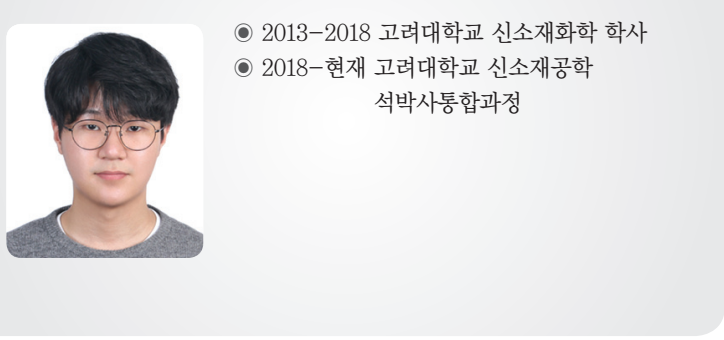

\section{ㅇㅇㅇㅗ 승 주}

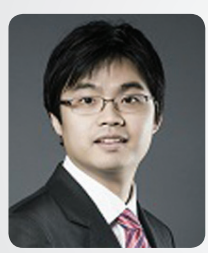

( ) 2001-2007 고려대학교 신소재공학 학사

0 2007-2008 한국 과학 기술연구원 (KIST) 위촉연구원

2008-2014 University of pennsylvania 재료공학과 박사

다 2014-2014 University of pennsylvania 박사 후 연구원

- 2014-2015 University of Illinois, Urbana, Chamapign 박사 후 연구원

( 2015-현재 고려대학교 신소재공학부 조교수 